\title{
NATIONAL IDENTITY AND THE QUEST OF ETHNIC AUTHORSHIP IN SARAWAK
}

\author{
Awang Azman Awang Pawi \\ apazman@cls.unimas.my
}

Centre for Language Studies

Universiti Malaysia Sarawak

\begin{abstract}
This article discusses aspects of identity building in the national literature of Sarawak. The author argues that the presence of a variety of authors in Sarawak is quite unique in expressing the ethnic diversity of Sarawak. This is because some of the ethnic writers include local colour in their writings. The situation is different in Peninsular Malaysia; although there are various ethnic groups such as Javanese, Banjar Bugis, Malaysian aborigines and Minang, there is little foregrounding of this in their writings, unlike what can be found in Sarawak. The ethnic diversity in Sarawak brings with it a number of ethnic issues, while at the same time representing problems that exist within these ethnic societies. The use of the national language in the works produced in Sarawak provides a national perspective without neglecting local issues that authors attempt to deal with. Authorship, theme and thinking, as well as the authors' attitudes in the works are also discussed in order to look at the dimension of national authorship in the context of local knowledge.
\end{abstract}

Keywords: national identity, ethnicity, authorship, national literature

\section{INTRODUCTION}

In the formation of a nation, national identity is one of the basic issues. Without looking at the status of a country, i.e. whether it is a developed or developing nation, aspects of national identity are often discussed. In 
developed countries such as South Korea, Japan, Germany, France or even the United States of America or Great Britain, aspects of national identity are clear. However, in a developing country, aspects of national identity are still being questioned. This study will discuss two important aspects in detail, that is, national identity and national literature in the context of Sarawak authorship. Therefore, national identity will be discussed first before aspects of national literature will be looked at in detail in order to provide a clearer perspective.

\section{THE QUESTION OF NATIONAL IDENTITY}

The question of national identity has been discussed by many scholars, activists and artists. There are several views on national identity in the world today. For example, Iran is depicted as "a country in search of an identity", South Africa is considered as being involved in a search for an identity, China is said to be dealing with the issue of building a national identity, while Taiwan is deconstructing and reconstructing its national identity. Apart from this, Syria and Brazil are said to be facing an identity crisis while Canada is said to be continually in such a crisis. Denmark, too, is said to be facing a deep identity crisis, while Algeria is experiencing a destructive one. The identity crisis faced by Turkey is said to be a unique one which is heating up the issue of a national identity, while Russia is undergoing its own serious identity crisis (Samuel Huntington, 2005:12-13).

Since the days when the decision was made to teach Science and Mathematics in English in schools, thinkers, activists and artists in Malaysia have felt that Malaysia is experiencing an identity crisis. In fact, even courses other than science or technology are being taught in English at universities (Hassan Ahmad, 2001). This situation has caused Malaysian Chinese to question whether Malays feel inferior or lack confidence in their own language. If the Malays themselves are unsure of their language, non-Malays will be confused (Lim Kim Hui, 2006:346-47). In fact, according to Lim Kim Hui, Malay scholars themselves have a deep-rooted inferiority complex where their language is concerned because they remain in the strong grip of English imperialism and have a fanatic adherence to an English/American tradition, both in their personal lives and in the academic world.

To change this view and this feeling of inferiority requires one to return to understanding the meaning of identity and the building of a national identity. A comprehensive understanding of the role of identity and identity-building 
will produce Malaysians that possess a national identity without feeling inferior to the rest of the world in the trend of globalization.

Individual identity is a social identity that is developed as a result of social interaction with other individuals, and this unique sense of personhood comes about as a result of one's own desires. A social identity, in turn, is a sense of belonging to a group. Each individual is able to identify points of similarity that they have in common with others in the group. Cultural identity is defined as a sense of belonging to a certain distinct ethnic, cultural or subcultural group (Warren Kidd, 2002:26).

Identity is important because it is capable of shaping human behaviour (Huntington, 2005:22). A person who feels himself to be a true Muslim would pray five times a day, and will refrain from doing anything that goes against the teachings of Islam even if his actions were to remain unknown to others. Such a person would practice a true Islamic lifestyle, regardless of time and place. Such behaviour would identify a true Muslim. The same is true of a Malay cultural identity. A person who identifies as truly Malay will try to adhere to the Malay values and a Malay lifestyle. If he does not, his society will label him as "not being Malay".

The identity of a nation can also be evaluated by other nations because each of its actions can be seen as representing the attitudes of the nation as a whole. If one nation does something to itself and this action goes against its values and the values of others, its action will cause it to be labelled as suffering from inferiority, a moral crisis, or of not having self-confidence. This is what is meant when it is said that identity has the ability to form the imagination of a nation.

\section{SOURCES OF IDENTITY}

There are at least five sources of identity (Huntington, 2005:27). The first source is the ascriptive element, that is, on which is influenced by age, ancestry, blood relation, ethnicity and race. The identity of a royal descendant is surely different from that of a commoner. The Indian ethnic identity is different from the Chinese ethnic identity. Similarly, someone whose background is a combination of three ethnicities is surely different from an individual who is born with only one ethnic background. The identity of teenagers is very different from the identity of senior citizens. Each identity comes with different behaviours and points of view. 
The second source of identity is based on culture. Among the aspects of culture are tribe, language, nation, religion and civilization. The German language and national identity are definitely different from the Chinese identity and national values. The values of an Islamic identity will definitely be different those of a Christian identity. The heritage of Greek civilization is different from the Arab civilizational heritage. Each will form its own identity.

Territory is also a source of identity; this includes one's neighbourhood, village town, city, federation, state, rural area, geographical area and hemisphere. Kelantan will surely have a different identity from California. The identity of youths from outlying areas will be different from that of city youths. In cities, the identity of working-class youths will be different from those of upper-middle-class youths.

In terms of political aspects, identity can be obtained and seen in the context of a clique, faction, leadership, target group, movement, party, ideology and country. The identity of the UMNO party differs from the identity of PAS. The identity of the ABIM leadership differs from that of the leadership of Sisters in Islam. The identity of Russia is different from the identity of the United States. This difference brings about differences in terms of decisions, opinions and attitudes.

Economic aspects also result in differences of identity. This includes the job, work group, workers, industry, economic sector, and workers' union. The identity of a white collar worker is different from that of a bluecollar worker. Among the white-collar class, differences are made between executives and non-executives. The identity of those involved in industry is different from those in the government sector. Each of these groups has its own perceptions concerning various issues in life and different attitudes in other matters.

Finally, social aspects are also sources of identity. Such sources are clubs, groups, friends, colleagues, entertainment groups and status. The identity of an executive club is different from that of an ordinary club, while the identity of fans of dangdut music will surely differ from those of fans of classical or jazz music. The identity of a minister differs from the identity of an ordinary parliamentary representative. In social interaction, the identity of a factory worker is different from the identity of an agricultural worker. In short, the sources of identity are of great variety. All aspects of these sources are dynamic in nature. 


\section{DEFINING A NATIONAL IDENTITY}

The meaning of "national identity" needs to be defined in order to create a clear understanding and wider perspective of the aspects of national identity and the formation of a national literature. According to Anthony Smith (2001:30), national identity is:

the maintenance and continuous reproduction of the pattern of values, symbols, memories, myths and traditions that composes the distinctive heritage of nations, and the identifications of individuals with that particular heritage and those values, symbols, memories, myths and traditions.

Apart from this, national identity and nation are complex constructs of identity because they consist of several components, that is, ethnic, cultural, territorial, economic, and legal-political components. Members of communities are bonded together through shared memories, myths and traditions that are different from the legal and bureaucratic bonds of states (Smith, 1991:15). In other words, the building of an identity is based on the cultural development and environment of an area.

Gellner (1983) has stated that a national identity fulfils a more intimate need, an internal function for an individual in a community. Clearer still is the socialization of a member as a "national" or "citizen". This is achieved today through compulsory, standardized public education systems by state authorities-education which is carried out repeatedly with commitment and with certain goals. Apart from this, certain implementations are also made to differentiate several issues through a homogenous culture and activities that are carried out fervently under the idealistic views of nationalists in cultures that are authentic in nature and reinforce unity. Anthony Smith has said that:

a sense of national identity provides a powerful means of defining and locating individual selves in the world, through the prism of the collective personality and its distinctive culture. It is through a shared, unique culture that we are enabled to know "who we are" in the contemporary world. By rediscovering that culture we "rediscover" ourselves, the "authentic self", or so it has appeared to many divided and disoriented individuals who have had to contend with the vast changes and uncertainties of the modern world. (1991:17) 


\section{National Identity and the Issue of Ethnic Authorship}

In the context of Sarawak authorship, the issue of national identity is a unique one. National identity in the context of Sarawak authorship can be seen in our national literature. One of the core concepts of our national literature is that the literature must be written in the national language. Even though national literature must be written in the national language, issues need not be national ones. What has been written is in the form of statements of issues about ethnicities which are highlighted in stages. The aim is to show the existence of ethnicities in Sarawak to provide a certain "flavour" to the national literature, and further, to reinforce that ethnic elements are not neglected in the national identity. In fact, the writings presented are able to provide some variety towards the formation of a national identity. The issues in the works reflect the attitudes of the authors where national literature is concerned. Writers are of various ethnicities such as Malays, Chinese, Iban, Lakiput, Melanau and others. For the purposes of this article, the discussion is limited to a select few.

\section{CHINESE AUTHORS AND MULTI-ETHNIC ISSUES}

In the context of Sarawak, the existence of writers of national literature among the ethnic Chinese has great significance as it provides various dimensions to a multi-ethnic life. The presence of Jong Chian Lai as a writer of national literature in Sarawak promises a bright future for the growth of literature in Malaysia. Jong Chian Lai does not only present aspects of Chinese life in his novel Pemberontakan (Revolution). In fact, Jong often presents ethnic Ibans in his works, including his novels Pindah (Moving) and Gugurnya Langit Hijau Nanga Tiga (The Fall of the Green Sky of Nanga Tiga).

To what extent is there the question of identity in the novel Gugurnya Langit Hijau Nanga Tiga? Looking at the theme presented by the author, it is development. The author wishes to express that the ethnic groups in Sarawak have never been against development. What is rejected by them is the manner in which this development is carried out. Such is the case with the inhabitants of the longhouse in Nanga Tiga, in Division Two of Sarawak.

Here, Jabau, a natural-born inhabitant of Nanga Tiga, is forced to face a number of challenges to protect the forest of Nanga Tiga from trespass by a group of people who are merely interested in its timber for their own enrichment. Jabau is forced to face Apai Icut, the headman of Nanga Tiga 
who is being used by Tauke Yap and Poling, who rapes Sunti, Jabau's former fiancée. Jabau's father dies when he is crushed by a tree. Jabau, who tries to complain to the authorities, is disappointed as they have been "paid off" by Tauke Yap.

If the felling of trees were done in a considerate manner, taking into consideration the interests of the rural folk and not causing social problems in their community, development would be readily accepted. This novel shows that in the beginning, the inhabitants of Nanga Tiga are divided in their opinions. However, because of the influence of Apai Icut and their desperate living conditions, they are forced to accept the planned development. However, at the end of the novel, a number of them have come to some kind of realization and are determined to confront Tauke Yap. Jabau gets carried away and beheads Poling and Tauke Yap. In the end, Jabau is shot dead by his own mother when he tries to kill Apai Icut. Here, it can be seen that even though Jabau's intentions are honourable, that is, to fight oppression, the traditional barriers-loyalty to the tribe's leader-cannot be compromised.

All this time, the national literature has focused a lot on Malay people, and on development. In Sarawak, the works considered as national literature that have been produced here are linked also to the existence of various ethnic groups and the issues they face. Such depictions may bring to attention the true issues of ethnic groups in Sarawak. Readers who do not belong to the Iban ethnic group will be able to understand the roots of issues in the ethnic Iban community. This will bring about mutual understanding and tolerance among the different ethnic groups. It is in this way that a national identity can be shaped-by together celebrating ethnic variety and understanding one another.

\section{ISSUES OF THE MELANAU ETHNIC GROUP}

The issues of the ethnic Melanau can be appreciated more comprehensively through the national literature. National identity is based on the understanding of ethnic groups which need to be viewed from certain perspectives. For example, the ethnic Melanau who are Muslims need to practice Muslim values in line with His revelation, whereas the Melanau who are pagans should be treated with respect if they perform actions in line with their beliefs. There should not be a mixing of culture and religious beliefs as this will cause a crisis of values. 
Jeli Bohari Bihar, a Melanau writer, has produced a short story titled "Pesta Kaul". This short story presents the opposition of modern, traditional and Islamic values. In the story, Meran is a character who holds fast to the belief that tradition far outweighs anything else in importance, whereas another character, Pak Jubai, wants to follow Islamic teachings strictly. One party in the story believes that if the pesta kaul (kaul festival) is not held, the ipok (spirit) of the sea will become angry and will manifest as storms, typhoons and lightning. The loss of Pak Putit, Pak Junit, Wak Suni and Kadir at sea near Mukah becomes the basis for the making offerings to the ipok so as to appease it. The opposing values of traditional and religious beliefs lie at the core of the conflict in this short story. The pesta kaul has been held for centuries as it is believed that bad things will happen if the ipok is not appeased.

The author also uses the technique of repetition in presenting Meran's idea of holding the pesta kaul. His rationale is that the sea has provided great bounty to the villagers, therefore it is time to repay the sea. Whoever refuses to celebrate the festival is deemed as having forgotten the traditions of the Melanau.

For those who hold on to Islamic teachings, this idea is unacceptable. In the work, this position is represented by a character named Pak Dubai. Conflict occurs because Pak Dubai insists that the kaul rituals are against Islamic teachings and whoever takes part in these is committing a grave $\sin$. He constantly refers to the teachings of Ustaz Isa, a religious teacher from the Peninsula who is stationed in Mukah. Ustaz Isa, in turn, is accused of destroying Melanau culture. Pak Dubai is accused of abandoning his culture and traditions in order to please Ustaz Isa for the sake of his child. Ustaz Isa is said to have no knowledge of the culture and traditions of the Melanau people.

The attitude of the author towards this issue is seen when he kills off the characters of Meran and Usu Derih who are lost during a typhoon. The author's views are based on his religious beliefs as a Muslim, which is that believing in spirits such as the ipok of the sea is heresy. God is believed to be more powerful than the ipok. Here, the concept of identity must be understood in more detail. The national identity must be understood as something that is to be shared, and yet, in questions pertaining to aqidah (creed or religious belief), one must have a strong stand. Confusion will arise if one is unable to distinguish between aspects of culture and religion. 


\title{
ISSUES OF THE IBAN ETHNIC GROUP
}

The act of writing and symbolism itself is based on the cultural atmosphere that surrounds the society and has a direct connection to the cultural identity and life of that society and ethnic group; this is also a new tendency especially when a postcolonial realization can be seen to have had an impact on the native inhabitants. What can be observed and commented on are the voices of that identity itself which can be said to be more authentic, meaningful and reflect the identity of the culture of that race. It is the little voices need to be brought to the forefront, in line with the development of postmodern theory that doubts metanarratives and deconstructs to obtain something that has long been sidelined by the voices of the centre, or the culture that has become deeply-rooted in the "cultural album" of the local populace. In writing about the Ibans, Douglas Jaga-the author of Kelingkang-has been very careful even though he is a native of Borneo himself. Perhaps this is because only a member of an ethnic group really understands the problems of that ethnic group first-hand. In Douglas case, he grew up within the experiences and knowledge of his people. In an interview conducted by Hajijah Jais (2000:3) with the author, he provided solid reasons for writing about his own people. He explained that:

\begin{abstract}
Antara bahan yang saya baca ialah bahan-bahan sastera yang ditulis oleh anak-anak Sarawak. Semuanya amat menarik. Cuma "sedikit" senario yang menyentuh masyarakat Iban yang agak kurang tepat dan terlalu umum. Maksud saya ialah terdapatnya amalan yang berunsur kedaerahan tapi diamalkan oleh keseluruhan masyarakat Iban. Oleh itu, saya cuba menulis sesuatu yang mungkin boleh diperbetul keadaan ini sekali gus memberi gambaran yang sebenarnya.
\end{abstract}

(Among the materials that I read was literature written by authors from Sarawak. These were all interesting. However, there were too few scenarios involving the Iban and they were rather inaccurate and far too general. I mean, there were practices that are specific to certain areas but presented as if they are practiced by all the Iban. Therefore, I tried to write something that would correct this situation and perhaps give a more realistic depiction.)

Douglas is of the opinion that the situation in literature that has some Iban elements was inaccurate and too general. Therefore, we can say that 
Kelingkang is an accurate and true example (in Douglas's point of view), and that this novel gives great authority to literature with Iban elements in Sarawak (Awang Azman Awang Pawi, 2001). I expect that Douglas will become even more critical upon reading the studies of Vinson H. Dutlive, Ling Roth and other orientalists who have written about the Iban. His statement is also a slap in the face of other non-Iban writers like Jong Chian Lai who includes a lot of Iban elements in his writings. It can also be considered a sign that Douglas considers it his duty as an Iban who has knowledge of literature and Iban society to depict the true situation of his people.

The realization about the identity of a race and racial realization has also been given much attention on a global scale. This can be seen from the writings of the well-known thinker, John Naisbitt, who, in his Global Paradox (1995) admits that the more the world becomes global, the more people become tribal, and the more they realize how important racial or ethnic identity is and must be maintained, preserved and continued. They realize that without an identity, an ethnic group could easily disappear in the current of globalization. Elements of ethnicity are seen to have the power to strengthen the identity of a society (Awang Azman \& Jeniri Amir, 2001). The Ibans are proud of practicing it through various rituals such as the gawai and miring, which highlight the uniqueness of their culture. Based on this, I am of the opinion that this was Douglas's main consideration in writing Kelingkang, which I feel is an important novel for Borneo. However, Douglas is extremely careful in filtering out the rituals and practices, especially the rites of passage, of the indigenous people who have practiced them for centuries. As a modern writer, Douglas is tied to modern forms of literature while at the same time is not able to put aside traditional values and cultural roots that lack strong intellectual arguments.

Apart from this, spiritual elements and ritual aspects cannot be avoided when analysing the traditional world-view of the Iban. It is these elements that influence the beliefs of the Iban, and this can be seen through various aspects of their lives, some of which are to be found in Kelingkang. The relationship between people and the magical world is tied to their environment, especially concerning illness, livelihood and so on. In Kelingkang, illness is said to befall a large number of longhouse inhabitants as a result of spirit possession. This belief is largely influenced by the environment in which these people live-the natural environment-which is so wide and complex that they submit to it and believe that they have to depend on magical powers and the supernatural. 
Tetapi bagi orang-orang di rumah panjangnya termasuk bapanya sendiri, Sada dirasuk hantu. Dirasuk roh nenek moyang yang telah marah kerana tidak diberi makanan yang cukup serta tidak disambut dengan jampi yang betul dan setimpal semasa hari Gawai Kelingkang yang pertama diadakan untuk Sada dulu. Ada yang mengatakan jampi yang dinyanyikan-nyanyikan oleh Lemambang Apai Kaluk ketika itu tidak sampai. Tidak memuaskan roh nenek moyang (Kelingkang, 1998).

(However, the people in the longhouse, including his father, believed that Sada was possessed by spirits. Possessed by the spirits of ancestors who were angry that they had not made enough offerings, and had not been received with the appropriate chants during the first day of the Gawai Kelingkang celebrations held for Sada. Some said that the chants recited by Lemambang Apai Kaluk had not reached their destination. Had not satisfied the spirits of the ancestors.)

This belief gives confidence to the inhabitants of the longhouse to get moving and realize their ideas concerning their relationship with nature and the supernatural world. According to this belief, the miring ritual becomes a symbol of Iban belief, the earliest religious ritual practiced in their lives. It is believed to be the individual's attempt to interpret his experiences and actions (including those in the world that he observes) in his religious life.

\section{ISSUES OF THE LAKIPUT TRIBE FROM THE KENYAH ETHNIC GROUP}

The Lakiput (Kiput) tribe is a Kenyah ethnicity that has specific characteristics and values in terms of traditions, customs, beliefs, do's and don'ts, practices, history and heritage. The Kiput are a tribe from the Berawan-Baram area in northern Sarawak, and belong to a subgroup of the Austronesian languages, the Malayo-Polynesian languages from the northwestern area of northern Sarawak. In 1981, the population numbered 2460, comprising people who spoke several dialects: Long Kiput, Long Tutoh (Kuala Tutoh), Lemiting, and the dialects related to Narom, Lelak, Tutong 2, Belait and Berawan (Wurm \& Hattori, 1981).

David Belulok is a young writer who has just emerged in Sarawak. He is descended from the Lakiput (Kiput) tribe of the Kenyah ethnic group and comes from the village of Kuala Tutoh in Baram. He received his primary 
education at SRK Kuala Tutoh before continuing his education at SMK Tutoh/Apoh, SMK Marudi and later Universiti Putra Malaysia, where he took a Bachelor's degree in the field of Human Development. His early interest in the field of literature can be seen from his involvement in poetry recitation contests during his school years, where he won second prize in 1987 and represented his school several times in drama competitions, and won the consolation prize in an essay competition in 2004. An early short story written by him was published in the Tunas Cipta magazine, while his earliest poem, titled "Bicara Melulu" (Aimless Talk) was published in the Yang Indah Itu Bahasa column in the Utusan Sarawaknewspaper. He is also a member of the Writer's Association of Sarawak, PUTERA.

\section{CAN THE SUBALTERN SPEAK LAKIPUT?}

The short story "Waris Perwira Sejati" (Descendants of a True Hero) published in Dewan Budaya is the story of Wak Lok, a Kenyah. When Belulok depicts how the Orang Ulu also contributed to the struggle against the colonial oppressors, he expresses the feelings of this ethnic group that their struggle should receive its due credit in history. The complaint of this young writer is a display of the complaints of his tribe, and is expressed in the following excerpt:

Perjuangan itu pula bukan hanya perjuangan orang-orang bandar seperti yang dibaca di perpustakaan sekolah. Bukan hanya perjuangan Rosli Dhobi, atau hanya perjuangan Rentap. Bagi Wak Lok, itulah perjuangan segenap lapisan masyarakat di Sarawak. Perjuangan semua rakyat yang bencikan penjajah. Perjuangan mereka yang inginkan kebebasan. Wak Lok kesal kerana perjuangan masyarakat Orang Ulu seperti dirinya tidak pernah ditulis menjadi sejarah. Tidak pernah diketahui oleh masyarakat umum.

(This struggle was not merely the struggle of the city folk such as can be read about in school libraries. It was not merely the struggle of Rosli Dhobi, or Rentap. To Wak Lok, it was the struggle of all levels of Sarawak society. The struggle of all citizens who hated the colonials. The struggle of everyone who wanted freedom. Wak Lok was upset that the struggles of the Orang Ulu, such as himself, had never made it into the history books. Never known to the public.) 
In this situation, it is the Orang Ulu themselves who need to write their own history because they know the roots of their anti-colonial thinking and struggle themselves. In fact, the details of their struggle are more easily obtained by them because they are closer. More importantly, they are the ones who have the most rights and authority over the interpretation of their struggle in line with their concept of resistance, and according to the thinking of their ethnic group.

However, as an author who realizes the contributions of his ethnic group, he tries to present this matter through creative means, and in this way, a part of it is based on fact or reality. It does not mean that the government has abandoned them as all ethnicities are given equal rights an indigenous people. According to the author:

Perjuangan Orang Ulu hanya menjadi sejarah bagi mereka yang pernah melalui keperitan peperangan. Keperitan hidup di tanah pedalaman. Keperitan inilah yang mengajar mereka erti ketabahan. Bukankah mereka juga berhak digelar perwira negara? Bukankah darah mereka turut tertumpah kerana mempertahankan daerah terpencil ini? Kerana tiada bukti sejarahlah maka kisah perjuangan mereka menjadi bahan ejekan anak-anak muda.

(The struggle of the Orang Ulu is only history to those who have gone through the hardship of war. The hardship of living in the interior. This hardship made them resolute. Were they not entitled to be considered national heroes? Was their blood not spilled to defend this remote district? It was only because there was no historical evidence, that the youngsters mocked him.)

The author also presents the dilemma of a freedom fighter whose struggle seems to have been forgotten by society. This dilemma is presented as the result of the younger generation of the ethnic group being unaware of such a contribution, resulting in them mocking Wak Lok when he talks about it. Perhaps this is what causes Wak Lok to become even more dejected. Therefore, he feels that it is necessary to erect a memorial for people like himself, so that they will not be made fun of and so that future generations would know about his contributions. According to the author:

Sudah setua ini tiada siapa yang ingin mendengar kisah perjuangannya. Perjuangan anak yang berasal dari pedalaman, 
anak rimba yang suatu ketika dahulu hingga kini tiada siapa peduli mati hidupnya. Memang dia sendiri tidak tahu apakah tujuan perjuangannya dulu. Apakah perjuangannya dulu sama seperti perjuangan-perjuangan orang lain. Apakah perjuangannya itu wajar dikenang dan diceritakan. Kalau sama, mengapa tiada tugu peringatan? Mengapa namanya dan mereka yang pernah berjuang bersamanya dulu tidak ditinta menjadi kenangan sepanjang hayat, biar anak cucu mereka tahu. Biar semua orang tahu. Orang tua yang terdampar dan terperuk di ceruk rimba ini, di dunia terpencil di tanah pedalaman ini pernah menjadi pejuang membebaskan negara.

(Until his old age now, no one wanted to hear the stories of his struggle. The struggle of a young man from the interior, a jungle boy whose life or death was of no consequence to anyone. Even he did not know the aim of his past struggles. Had it been the same struggle as everyone else's? Should it be remembered and retold? If it was the same, why was there no memorial? Why was his name and the names of the others who fought alongside him not recorded as history, to be known by future generations? Let everyone know. The old man cast off and obscure in this far corner of the jungle had once been a warrior fighting for the country's freedom.)

This text about the Lakiput ethnic group depicts the problems of the local populace seen through the eyes of the locals. As their struggle is not recorded in any of the great historical texts, it causes this text which concerns the thinking of the Lakiput to be labelled as belonging to "the other", which receives less attention by society and even the ethnic group itself. Also, there is a return of the phenomenon of Western researchers studying the East, which is partly to be blamed on the ethnic group itself. This is among the essence of what is expressed by the author, that the ethnic group itself has a greater right to express its views and to represent its own problems, thinking and dilemmas in this post-colonial era. Of course, not all of the Lakiput have forgotten their own culture. However, it is not well-understood by the younger generation, and perhaps only time will tell. I believe the text presented by this author, himself being a Kenyah of the Lakiput tribe, expresses an ethnic identity echoes an aura of post-colonialism. Surely, the author provides an ethnic perspective and is able to penetrate the thinking and culture of the Lakiput. 


\section{CONCLUSION}

The authors of national literature in Sarawak come from a variety of ethnic backgrounds. The works produced by them present a number of ethnic issues that give these works a local face and flavour. What this means is that the national literature is enriched through local issues. Their presence as writers is important in Sarawak to express the aspects of ethnicity and identity which are different in terms of culture. All this while, their voices have been heard very little in creative works. However, beginning from the 1990s, the voices of ethnic writers have become more widely heard in the local and national mass media. The various ethnic writings in the national language are capable of promoting unity as they allow the sharing of opinions, ideas, events, history and society in more detail.

\section{REFERENCES}

Awang Azman Awang Pawi \& Jeniri Amir, 2001. Kaul: Suatu Interpretasi Sosiobudaya. Kota Samarahan: UNIMAS.

David Belulok. "Waris Perwira Sejati" in Dewan Budaya, Mac 2005.

Douglas Jaga, 1998. Kelingkang. Kuala Lumpur: Dewan Bahasa dan Pustaka.

Kidd, Warren, 2002. Culture and Identity. Houndmills: Palgrave.

Gellner, Ernest,1983. Nations and Nationalism. Oxford: Blackwell.

Hajijah Jais, 2000. "Pertembungan Dua Nilai yang belum Terjawab dalam

Novel Kelingkang". Anjuran Bahagian Teori dan Kritikan Sastera, Jabatan Sastera, Dewan Bahasa dan Pustaka. May 2000.

Huntington, Samuel P., 2005. Who Are We? America's Great Debate. Sydney: Australia.

Jeli Bohari Bihar. "Pesta Kaul: Yang Indah itu Bahasa" in Borneo Post. 19 October 1992.

Jong Chian Lai, 1990. Gugurnya Langit Hijau Nanga Tiga. Kuala Lumpur: Dewan Bahasa dan Pustaka.

Lim Kim Hui, 2006. Penulis Bukan Melayu dalam Konteks Pembinaan Sastera Nasional di Malaysia in Mohamad Saleeh Rahamad. Persuratan dan Peradaban Nasional, pp. 345-66.

Naisbitt, J., 1995. Global Paradox. BCA: New York. 
MALAY LITERATURE

Smith, Anthony D., 1991. National Identity. Reno: University of Nevada Press.

Smith, Anthony D., 2001. Nationalism: Theory, Ideology, History. Cambridge: Polity Press.

Welyne Jefrey Jehom, "Ethnic Pluralism and Ethnic Relation in Sarawak" in Akademika 61, July, pp. 53-70, 2002.

Woodward, K. (ed.), 1997. Identity and Difference. London: Sage.

(Translated by Tanja Jonid) 